J. Dairy Sci. 92:895-906

doi:10.3168/jds.2008-1796

(c) American Dairy Science Association, 2009.

\title{
Effect of exopolysaccharides on the proteolytic and angiotensin-I converting enzyme-inhibitory activities and textural and rheological properties of low-fat yogurt during refrigerated storage
}

\author{
L. Ramchandran and N. P. Shah ${ }^{1}$ \\ Faculty of Health Engineering and Science, Victoria University, Werribee Campus, PO Box 14428, Melbourne, Victoria 8001, Australia
}

\begin{abstract}
The aim of this study was to examine the influence of using exopolysaccharide (EPS) producing strain of Streptococcus thermophilus on the viability of yogurt starters, their proteolytic and angiotensin-I converting enzyme-inhibitory activities, and on the textural and rheological properties of the low-fat yogurt during storage at $4^{\circ} \mathrm{C}$ for $28 \mathrm{~d}$. The use of an EPS-producing strain of $S$. thermophilus did not have influence on $\mathrm{pH}$, lactic acid content, or the angiotensin-I converting enzymeinhibition activity of low-fat yogurt. However, EPS showed a protective effect on the survival of Lactobacillus delbrueckii ssp. bulgaricus. Presence of EPS reduced the firmness, spontaneous whey separation, yield stress, and hysteresis loop area but not the consistency and flow behavior index of low-fat yogurt.
\end{abstract}

Key words: exopolysaccharide, proteolysis, angiotensin-I-converting-enzyme, rheology

\section{INTRODUCTION}

Exopolysaccharides (EPS) are long-chain polysaccharides consisting of branched, repeating units of sugars or sugar derivatives. Lactic acid bacteria (LAB) are able to produce several types of polysaccharides that are classified according to their location relative to the cell. Those that are excreted outside the cell wall are called exocellular polysaccharides or EPS whereas those that form adherent cohesive layers are called capsular polysaccharides. The EPS can either be loosely attached or completely excreted into the medium as a slime (Ruas-Madiedo et al., 2002). Exopolysaccharides from LAB have proved to be invaluable in their application to the improvement of rheology, texture, and mouthfeel of fermented milk products such as yogurt, particularly in low-fat yogurts. Exopolysaccharides

Received October 8, 2008.

Accepted November 4, 2008.

${ }^{1}$ Corresponding author: Nagendra.Shah@vu.edu.au produced by LAB are reported to improve the texture and firmness, reduce thermal and physical shock and syneresis, and increase the viscosity of yogurt (DeVuyst and Degeest, 1999; Hugenholtz and Smid, 2002; Jolly et al., 2002; Ruas-Madiedo et al., 2002; Broadbent et al., 2003; Welman and Maddox, 2003; Sodini et al., 2004). The EPS produced by LAB are also reported to provide physiological benefits such as lowering cholesterol, immunomodulation, and antitumor activity (Hugenholtz and Smid, 2002; Welman and Maddox, 2003).

Certain strains of both of the yogurt starter cultures, namely Streptococcus thermophilus and Lactobacillus delbrueckii ssp. bulgaricus, are known to produce heteropolysaccharides. The quantity of EPS ranges from 50 to $350 \mathrm{mg} / \mathrm{L}$ of fermented milk for $S$. thermophilus and 60 to $150 \mathrm{mg} / \mathrm{L}$ for Lb. delbrueckii ssp. bulgaricus (Ruas-Madiedo et al., 2002). Although these organisms produce EPS at low levels, they still contribute to the texture, mouthfeel, taste perception, and stability of the final products (Doleyres et al., 2005). Growth conditions, type of nutrients available, and the strain of the organism are among the factors that influence the yield and type of EPS produced. In most industrial fermentations, EPS-producing strains of S. thermophilus are the rational choice for products like yogurt mainly due to their minor role in proteolysis during milk fermentation (De Vuyst et al., 2003).

Yogurt already has an established image as a healthy food. The consumption of yogurt to maintain good health is a long tradition in many countries. It is now established that several peptide sequences are encrypted in milk proteins that have the potential to provide several physiological and health benefits to the consumer. These peptides are referred to as bioactive peptides (Clare and Swaisgood, 2000; Shah, 2000). Milk fermentations using LAB release these peptides (Meisel and Bockelmann, 1999; Gobbetti et al., 2002) which are reported to provide several health benefits. Peptides that provide antihypertensive effects have caught the interest of scientists, manufacturers, and consumers. These peptides are understood to have the potential to inhibit the activity of angiotensin-I converting enzyme 
(ACE) and thereby regulate blood pressure. Several ACE-inhibitory peptides have been isolated from fermented milk and commercial dairy products (Shah, 2000; Lopez-Fandino et al., 2006; Hayes et al., 2007).

In the last few years, consumer interest has turned toward low-fat yogurts. This changing trend has generated interest in solving the major textural problem of low-fat yogurts, namely, whey separation. Spontaneous syneresis refers to the loss in the ability of the yogurt gel to entrap all of the serum phase due to the weakening of the gel network (Lucey, 2002). Moreover, yogurt texture is extremely fragile. As a result, mechanical handling of the product is difficult. Some of the common methods adopted by manufacturers to address this problem have been to increase the level of nonfat milk solids or to add sugar, proteins, natural or synthetic gums, and stabilizers. Another suggested method for improving the texture of low-fat yogurt is enzymatic stimulation of protein interactions in milk (Faergemand et al., 1999; Lorenzen, 2002; Shah, 2003; Welman and Maddox, 2003; Ozer et al., 2007; Xu et al., 2008). However, these methods are limited when faced with the increasing consumer demand of low-fat/sugar products with no additives and stabilizers (Jolly et al., 2002). A viable alternative to this is the use of EPS-producing cultures (De Vuyst et al., 2003). Hence, the in situ use of generally recognized as safe, food-grade, EPS-producing strains of LAB as functional starters in fermented food products appears to be a feasible solution.

Much of the work related to EPS-producing starters have concentrated on their influence on the viscosity, rheology, and texture of yogurt (Hassan et al., 2003a; Zisu and Shah, 2003; Guzel-Seydim et al., 2005; Amatayakul et al., 2006; Girard and Schaffer-Lequart, 2007; Purwandari et al., 2007). So far, no work has been carried out to study the influence of EPS-producing starters on the stability of the ACE-inhibitory activity of fermented milks such as yogurt. Also, very little work has been carried out to monitor the changes in the textural and rheological properties of yogurt made from EPS-producing strains of starters during storage. This study was carried out with the objective of comprehensively studying the influence of an EPS-producing strain of $S$. thermophilus on the viability of $S$. thermophilus and Lb. delbrueckii ssp. bulgaricus, changes in $\mathrm{pH}$ and lactic acid content, proteolysis, and ACE-inhibitory activity, as well as on the firmness, spontaneous whey separation, and rheological parameters during storage of the low-fat yogurt at $4^{\circ} \mathrm{C}$. The yield of EPS was also monitored during the period of storage.

\section{MATERIALS AND METHODS}

\section{Propagation of Yogurt Starters}

Two strains of $S$. thermophilus, one EPS producer (1275) and one non-EPS producer (1342), were obtained from the Starter Culture Collection of Victoria University (Werribee, Victoria, Australia). It has been established that $S$. thermophilus 1275 produces capsular as well as ropy EPS (Zisu and Shah, 2003). Lactobacillus delbrueckii ssp. bulgaricus 1368 was obtained from Australian Starter Culture Research Centre Ltd. (Werribee, Victoria, Australia). All 3 organisms were stored as frozen cultures in $40 \%$ (wt/vol) glycerol at $-80^{\circ} \mathrm{C}$. The cultures were activated by transferring first in M17 medium for S. thermophilus and in de Man, Rogosa, and Sharpe medium for Lb. delbrueckii ssp. bulgaricus. Thereafter, the cultures were transferred once each to sterile reconstituted skim milk (RSM; $12 \%$ wt/vol) containing $1 \%$ yeast extract and $2 \%$ glucose (wt/vol) and sterile RSM (sterilized by autoclaving at $121^{\circ} \mathrm{C}$ for 15 min) before preparing the bulk cultures. For each transfer, the rate of inoculation was $1 \%$ (vol/vol) and the temperature of incubation was $37^{\circ} \mathrm{C}$ for $S$. thermophilus and $42^{\circ} \mathrm{C}$ for $L b$. delbrueckii ssp. bulgaricus for a period of $20 \mathrm{~h}$ each.

\section{Yogurt Making}

Low-fat yogurt was prepared using skim milk (Skinny Milk, Parmalat Australia Ltd., Brisbane, Queensland, Australia) that was standardized to $12 \%$ total solids with skim milk powder. The milk was preheated to $60^{\circ} \mathrm{C}$, at which stage the skim milk powder was added. The heating was then continued to a temperature of $85^{\circ} \mathrm{C}$ and the heated yogurt mix was held at this temperature for $30 \mathrm{~min}$, followed by cooling to $45^{\circ} \mathrm{C}$ in a water bath maintained at about $4^{\circ} \mathrm{C}$. The heating and cooling processes were carried out in a closed container to minimize losses due to evaporation. This was followed by inoculation with $S$. thermophilus and $L b$. delbrueckii ssp. bulgaricus, each at the rate of $1 \%$ (wt/vol). The inoculated mix was then mixed thoroughly, dispensed in 50-mL polystyrene cups with lids, and incubated at $42^{\circ} \mathrm{C}$ until the $\mathrm{pH}$ decreased to $4.5 \pm 0.1$. The fermentation was stopped by transferring the cups immediately to a walk-in refrigerator maintained at $4 \pm 1^{\circ} \mathrm{C}$. Two batches of yogurt were prepared; one using the nonEPS strain of $S$. thermophilus 1342 (NEY; control batch) and the other using the EPS-producing strain of S. thermophilus 1275 (EY; experimental batch). 


\section{Sampling of Yogurt Mixes and Yogurt for Analyses}

The samples of inoculated yogurt mixes $(0 \mathrm{~h})$ were removed before incubation for determining the viable counts, $\mathrm{pH}$, and lactic acid content, and for measuring proteolysis and ACE-inhibition activity. Samples of both types of low-fat yogurt were removed from the refrigerated storage at $18 \mathrm{~h}$ postmanufacture. This was referred to as the 1 sample. Samples were also removed at $\mathrm{d} 7,14,21$, and 28 of storage at $4^{\circ} \mathrm{C}$ and analyzed for changes in $\mathrm{pH}$, lactic acid content, viability of starter cultures, yield of EPS, proteolysis by o-phthaldialdehyde (OPA) method, and ACE-inhibitory activity, as well as for firmness, spontaneous whey separation, and rheological parameters.

\section{Preparation of Filtrates for Analysis of Proteolysis by OPA Method and ACE-Inhibitory Activity}

The filtrates of inoculated samples $(0 \mathrm{~h})$ were prepared by lowering their $\mathrm{pH}$ to 4.5 with glacial acetic acid followed by centrifugation at $4,000 \times g$ for 30 min at $4^{\circ} \mathrm{C}$. Filtrates of low-fat yogurt samples stored at $4^{\circ} \mathrm{C}$ were prepared by centrifuging (Sorvall R2 7 , Thermo Scientific, Waltham, MA) at $4,000 \times g$ for 30 min at $4^{\circ} \mathrm{C}$. All the supernatants thus obtained were filtered through a $0.45-\mu \mathrm{m}$ membrane filter and stored at $-20^{\circ} \mathrm{C}$ until assayed.

\section{Measurement of $\mathrm{pH}$}

The changes in $\mathrm{pH}$ in the yogurts during preparation and storage were measured using a $\mathrm{pH}$ meter (model 8417, Hanna Instruments, Singapore).

\section{Determination of Lactic Acid}

The concentration of lactic acid (mg/100 g of yogurt) in all samples of low-fat yogurt stored at $4^{\circ} \mathrm{C}$ as well as the $0 \mathrm{~h}$ samples of mixes were determined by HPLC as described by Ramchandran and Shah (2008). Briefly, 40 $\mu \mathrm{L}$ of $15.5 M$ nitric acid and $500 \mu \mathrm{L}$ of $0.005 M$ sulfuric acid were added to $1 \mathrm{~g}$ of the sample, mixed, and centrifuged for $30 \mathrm{~min}$ at 14,000 $\times \mathrm{g}$ in an Eppendorf 5415C centrifuge (Crown Scientific, Melbourne, Victoria, Australia). The supernatant thus obtained was passed through a $0.45-\mu \mathrm{m}$ membrane filter into HPLC vials. The lactic acid was separated in an Aminex HPX-87H, $300 \times 7.8 \mathrm{~mm}$ ion exchange column (BioRad Life Science Group, Hercules, CA) fitted with a guard column maintained at $65^{\circ} \mathrm{C}$. The column was attached to a Varian HPLC (Varian Analytical Instruments, Walnut Creek, CA) fitted with a UV/Vis detector. The sample injection volume was $20 \mu \mathrm{L}$, which was eluted using
$0.005 M$ sulfuric acid as mobile phase at a flow rate of $0.6 \mathrm{~mL} / \mathrm{min}$ and the separated lactic acid was detected at $220 \mathrm{~nm}$. The standard working solutions of $\mathrm{L}(+)$ lactic acid (prepared from a stock solution of 5.1990 $\mathrm{g} / 50 \mathrm{~mL}$ ) was used to compare those of the samples.

\section{Viability of S. thermophilus and Lb. delbrueckii ssp. bulgaricus}

The enumeration of S. thermophilus 1275 and 1342 and $L$ b. delbrueckii ssp. bulgaricus 1368 , in freshly inoculated mixes $(0 \mathrm{~h})$ and in the low-fat yogurts stored at $4^{\circ} \mathrm{C}$, was carried out at weekly intervals by pour plate technique using M17 agar and reinforced clostridial agar, respectively (Dave and Shah, 1996). The counts were reported as $\log _{10}$ cfu per gram of yogurt sample. In the results presented, the $0 \mathrm{~h}$ counts were subtracted from each of those of the yogurt samples to show the actual changes in counts due to growth of the yogurt starters during storage at $4^{\circ} \mathrm{C}$ for $28 \mathrm{~d}$.

\section{Determination of Crude EPS Content}

The quantity of crude EPS in the EY samples was measured during the storage period of $28 \mathrm{~d}$ at $4^{\circ} \mathrm{C}$ by the method of vanGeel-Schutten et al. (1998) as described by Purwandari et al. (2007) with some modifications. The method involved centrifugation of $50 \mathrm{~g}$ of yogurt at $11,000 \times g$ for $10 \mathrm{~min}$ at $4^{\circ} \mathrm{C}$. The supernatant containing the EPS was collected and mixed with 2 volumes of cold ethanol and left at $4^{\circ} \mathrm{C}$ for about 18 to $20 \mathrm{~h}$ to precipitate the EPS. This was followed by centrifugation at $11,000 \times g$ for $15 \mathrm{~min}$ at $4^{\circ} \mathrm{C}$. The precipitates thus obtained were dissolved in $20 \mathrm{~mL}$ of Milli-Q water (Millipore Corp., Billerica, MA), mixed with $500 \mu \mathrm{L}$ of $80 \% \mathrm{TCA}$, and left at $4^{\circ} \mathrm{C}$ for another 18 to $20 \mathrm{~h}$ to precipitate the proteins. This was followed by centrifugation at $2,000 \times g$ for $15 \mathrm{~min}$ at $4^{\circ} \mathrm{C}$. The protein-free supernatant was collected and mixed with 2 volumes of cold ethanol and left at $4^{\circ} \mathrm{C}$ for 18 to 20 $\mathrm{h}$ to re-precipitate the EPS. The EPS precipitates were collected by centrifuging at $2,000 \times g$ for $15 \mathrm{~min}$ at $4^{\circ} \mathrm{C}$. The steps of protein precipitation and EPS reprecipitation were repeated once more and the EPS finally collected by centrifuging at $2,000 \times g$ at $4^{\circ} \mathrm{C}$ for $15 \mathrm{~min}$. The collected crude EPS was dried at $40^{\circ} \mathrm{C}$ until 2 consecutive weights did not show a difference of more than $0.001 \mathrm{~g}$. The results were expressed as milligrams of crude EPS per $100 \mathrm{~g}$ of yogurt.

\section{Extent of Proteolysis by OPA Method}

The extent of proteolysis was determined by measuring the free amino acid content in filtrates (prepared 
as mentioned previously) of yogurt mixes (0 h) as well as of low-fat yogurt samples by the method of Church et al. (1983) as described by Ramchandran and Shah (2008). To $150 \mu \mathrm{L}$ of the filtrate, $3 \mathrm{~mL}$ of $o$-phthaldialdehyde (OPA) reagent was added, vortexed for $5 \mathrm{~s}$, followed by measuring absorbance at $340 \mathrm{~nm}$ within 2 min using NovaSpec-II spectrophotometer (Pharmacia, Biotech, Uppsala, Sweden). The readings of the $0 \mathrm{~h}$ samples as well as the reagent blank were deducted from the corresponding readings of yogurt samples to obtain the amount of free amino acids released because of the proteolytic activity of the starter cultures during fermentation and storage.

\section{Determination of ACE-Inhibitory Activity}

The ACE-inhibitory activity was determined in the filtrates of yogurt mixes as well as of the low-fat yogurts by the method of Cushman and Cheung (1971) as described by Ramchandran and Shah (2008). Briefly, 200 $\mu \mathrm{L}$ of hippuryl-histidyl-leucine ( $5 \mathrm{~m} M$ in $0.1 M$ borate buffer) was mixed with $60 \mu \mathrm{L}$ of borate buffer $(0.1 \mathrm{M}$ solution containing $0.3 \mathrm{M} \mathrm{NaCl}, \mathrm{pH} 8.3$ ) and $30 \mu \mathrm{L}$ of the filtrate and incubated at $37^{\circ} \mathrm{C}$ for $10 \mathrm{~min}$. Thereafter, $20 \mu \mathrm{L}$ of ACE enzyme solution $(0.1$ unit $/ \mathrm{mL})$ was added and the tubes incubated at $37^{\circ} \mathrm{C}$ for $30 \mathrm{~min}$. The enzyme activity was terminated with $250 \mu \mathrm{L}$ of $1 M$ $\mathrm{HCl}$. The hippuric acid formed was extracted by mixing in $1.7 \mathrm{~mL}$ of ethyl acetate. After quiescent standing for $10 \mathrm{~min}, 1.2 \mathrm{~mL}$ of the separated solvent layer was siphoned out and dried on a boiling water bath. The dried hippuric acid was dissolved in $1 \mathrm{~mL}$ of deionized water and absorbance measured at $228 \mathrm{~nm}$ using $\mathrm{UV} /$ Vis Pharmacia, LKB-UltrospecIII spectrophotometer (Pharmacia, Uppsala, Sweden). The percentage inhibition was calculated using the following formula:

$$
\operatorname{ACE} \text { inhibition }(\%)=\left[1-\frac{C-D}{A-B}\right] \times 100,
$$

where $\mathrm{A}$ is the absorbance in the presence of $\mathrm{ACE}$ and without the sample, $\mathrm{B}$ is the absorbance without both $\mathrm{ACE}$ and the sample, $\mathrm{C}$ is the absorbance with $\mathrm{ACE}$ and the sample, and D is the absorbance with the sample but without ACE. The ACE inhibition was also expressed in terms of $\mathrm{IC}_{50}$, defined as the protein concentration in the sample $(\mathrm{mg} / \mathrm{mL})$ required to inhibit $50 \%$ of the ACE activity. The protein content of the filtrates was determined by the method of Lowry et al. (1951) using BSA as a standard.

\section{Firmness of Yogurt}

The firmness of the low-fat yogurts, measured as the force required to break the gel, was determined using a texture analyzer TA-XT.2 (Stable Micro Systems, Godalming, UK) with a P20 probe (diameter $20 \mathrm{~mm}$ ) and $25-\mathrm{kg}$ load cell. The speed of penetration was set at $1 \mathrm{~mm} / \mathrm{s}$ and the depth of penetration was set at $10 \mathrm{~mm}$. The ratio of cup diameter to probe diameter was 3.5:1 (Amatayakul et al., 2006). The measurements were performed as soon as the samples were removed from the refrigerator. The firmness of the yogurt samples was expressed in $g$.

\section{Spontaneous Whey Separation}

Spontaneous whey separation in the stored low-fat yogurt, indicative of the whey expelled from the gel without the application of external pressure, was determined by the siphon method described by Amatayakul et al. (2006). A cup of yogurt was weighed immediately after removing from the refrigerator and tilted at an angle of $45^{\circ}$ to collect the surface whey. The collected whey was siphoned out with a syringe to which a needle was attached. The siphoning was performed within $10 \mathrm{~s}$ to avoid forced leakage of whey from the curd. Thereafter, the cups were weighed and whey separation calculated by dividing the weight of whey siphoned with the initial weight of yogurt and the results were expressed as percentage spontaneous whey separation.

\section{Rheological Measurements}

The low-fat yogurt stored at $4^{\circ} \mathrm{C}$ was gently stirred 5 times before rheological analysis. The viscoelastic properties were determined by small amplitude oscillatory measurement using a controlled stress/controlled rate rheometer (Physica MCR 301, Anton Paar GmbH, Ostfildern, Germany). The rheometer was equipped with a temperature and moisture regulating hood and coneplate geometry (CP50-1, $50 \mathrm{~mm}$ diameter, $1^{\circ}$ angle, and $0.02 \mathrm{~mm}$ gap, Anton Paar). The temperature of the system was regulated by a viscotherm VT2 circulating bath and controlled at $5 \pm 1^{\circ} \mathrm{C}$ with a Peltier system (Anton Paar). The data of the rheological measurements were analyzed with the supporting software Rheoplus/32 V2.81 (Anton Paar). A portion of the stirred samples was loaded on the inset plate and presheared at a shear rate of 500 per s for $30 \mathrm{~s}$ and then equilibrated for 150 $\mathrm{s}$ to allow structure rebuilding before small amplitude oscillatory measurement was performed. The samples were first subjected to a frequency sweep test using a frequency ramp from 0.1 to $10 \mathrm{~Hz}$ at a constant strain of $0.5 \%$ (determined from an amplitude sweep at $1 \mathrm{~Hz}$ ) to ascertain the viscoelastic properties. The shear rate, storage modulus, loss modulus, and damping factors were recorded for all the samples. This was followed by a shear rate sweep to generate the flow curves. The 
shear stress was measured as a function of shear rates from 0.1 to 100 per s (upward and downward sweeps). The flow behavior of the samples was determined by using the Herschel-Bulkley model which is as follows:

$$
\sigma=\sigma_{0}+k \cdot \dot{\gamma}^{n}
$$

where $\sigma_{0}$ is the yield stress, $k$ is the consistency index, $\dot{\gamma}$ is the shear rate and $n$ is a dimensionless number that indicates the closeness to Newtonian flow $(n<1$ indicates pseudoplastic liquid). The larger the value of $k$, the thicker the product and therefore, the more viscous the fluid (Bourne, 2002). The hysteresis loop area between the upward and downward curves was also calculated using the RheoWin Pro software (Anton Paar).

\section{Experimental Design and Statistical Analysis}

The yogurt making experiment was designed with culture (strains of $S$. thermophilus) and replications as the main plot and time as the subplot. This block was replicated 3 times with 2 subsamplings. The results of the various determinations were analyzed as split plot in time using the GLM procedure of SAS (SAS Institute, 1996). The data of EPS concentration was analyzed by one-way ANOVA and Tukey's test for multicomparison of the means. Correlational analysis was employed, where appropriate, using Microsoft Excel Statpro software. The level of significance was set at $P=0.05$.

\section{RESULTS AND DISCUSSION}

\section{Changes in $\mathrm{pH}$}

On average, EY took more time (287 min) than NEY (277 $\mathrm{min})$ to reach the $\mathrm{pH}$ of $4.5 \pm 0.1$. An early gelation in the presence of EPS-producing cultures has been reported to inhibit the mobility of the growing organisms (Hassan et al., 2002). This could explain, in part, the possible reason for the increased fermentation time observed in EY. On the contrary, Doleyres et al. (2005) have reported that yogurt prepared using EPS-producing cultures fermented faster than those prepared using non-EPS cultures.

During storage at $4^{\circ} \mathrm{C}$, both the types of yogurt showed a sharp decrease $(P<0.05)$ in $\mathrm{pH}$ at $\mathrm{d} 7$ followed by a sharp increase $(P<0.05)$ at $d 21$ of storage (Table 1$)$. This was concomitant with the significant increase in lactic acid content of the yogurts (Table 1). There were no significant variations in $\mathrm{pH}$ of yogurts during the other periods of storage. Purwandari et al. (2007) also observed that S. thermophilus 1275 stopped producing acid in yogurt after $7 \mathrm{~d}$ of storage at $4^{\circ} \mathrm{C}$. However, the $\mathrm{pH}$ at the end of storage was almost the same as that at the start (d 1) for both NEY and EY. The variation in the strain of $S$. thermophilus (NEY strain vs. EY strain) did not have any influence on the changes in $\mathrm{pH}$ throughout the storage period. The increase in $\mathrm{pH}$ toward the end of storage period could be attributed to the ability of $S$. thermophilus to produce certain basic metabolites (Tinson et al., 1982). This is in contrast to the observations of Ozer et al. (2007), Purwandari et al. (2007), and Al-Kadamany et al. (2003) who observed a continuous decrease in $\mathrm{pH}$ of yogurts during storage whereas Salvador and Fiszman (2004) did not observe any change in $\mathrm{pH}$ of yogurt during storage. These differences could be due to the different types and combination of starters used for yogurt making by these researchers.

\section{Changes in Lactic Acid}

The concentration of lactic acid (mg/100 g of yogurt) in the control and experimental yogurts stored at $4^{\circ} \mathrm{C}$ for $28 \mathrm{~d}$ is shown in Table 1 . The amount of lactic acid produced was not influenced by the strain of $S$. thermophilus used for making yogurt. All the yogurts showed an increase in lactic acid content $(P<0.05)$ by 0.37 to $0.39 \mathrm{mg} / 100 \mathrm{~g}$ of yogurt during the first week (d 7) of storage, after which there were no significant changes in the concentration of lactic acid. Amatayakul et al. (2006) did not observe any influence of the type of starter on the amount of lactic acid produced, although they reported slight increases in the lactic acid content during the 28-d storage period. On the contrary, Guzel-Seydim et al. (2005) reported significantly higher concentration of lactic acid in yogurts produced with a ropy cultures and a decrease in the content after 14 d storage at $4^{\circ} \mathrm{C}$. These variations could be due to the differences in the strains of organisms used for yogurt making.

\section{Viability of S. thermophilus and Lb. delbrueckii ssp. bulgaricus}

The change in the number of EY strain of $S$. thermophilus, NEY strain of S. thermophilus, and Lb. delbrueckii ssp. bulgaricus 1368 during storage is reported in Table 2. Among the strains of S. thermophilus, the counts of the NEY strain remained similar throughout the storage period, whereas the EY strain showed an increase $(P<0.05)$ at $\mathrm{d} 14$ and a decrease $(P<$ $0.05)$ at $\mathrm{d} 28$, although their numbers at $\mathrm{d} 28$ were similar to those at the start of storage (d 1). Also, the increase in the counts of EY strain of $S$. thermophilus 
Table 1. Changes in $\mathrm{pH}$ and lactic acid concentration during storage of control (NEY) ${ }^{1}$ and experimental (EY) low-fat yogurts at $4^{\circ} \mathrm{C}$ for $28 \mathrm{~d}^{2}$

\begin{tabular}{|c|c|c|c|c|c|}
\hline \multirow[b]{2}{*}{ Type of yogurt } & \multicolumn{5}{|c|}{ Period of storage $(\mathrm{d})$} \\
\hline & 1 & 7 & 14 & 21 & 28 \\
\hline \multicolumn{6}{|l|}{$\mathrm{pH}$} \\
\hline NEY & $4.53^{\mathrm{a}, \mathrm{A}}$ & $4.40^{\mathrm{b}, \mathrm{A}}$ & $4.34^{\mathrm{b}, \mathrm{A}}$ & $4.58^{\mathrm{a}, \mathrm{A}}$ & $4.53^{\mathrm{a}, \mathrm{A}}$ \\
\hline EY & $4.52^{\mathrm{a}, \mathrm{A}}$ & $4.44^{\mathrm{b}, \mathrm{A}}$ & $4.33^{\mathrm{bc}, \mathrm{A}}$ & $4.54^{\mathrm{a}, \mathrm{A}}$ & $4.48^{\mathrm{ab}, \mathrm{A}}$ \\
\hline SEM & & & 0.024 & & \\
\hline \multicolumn{6}{|c|}{ Lactic acid (mg/100 g of yogurt) } \\
\hline NEY & $0.75^{\mathrm{a}, \mathrm{A}}$ & $1.14^{\mathrm{b}, \mathrm{A}}$ & $1.21^{\mathrm{b}, \mathrm{A}}$ & $1.21^{\mathrm{b}, \mathrm{A}}$ & $1.20^{\mathrm{b}, \mathrm{A}}$ \\
\hline $\mathrm{EY}$ & $0.75^{\mathrm{a}, \mathrm{A}}$ & $1.12^{\mathrm{b}, \mathrm{A}}$ & $1.21^{\mathrm{b}, \mathrm{A}}$ & $1.26^{\mathrm{b}, \mathrm{A}}$ & $1.21^{\mathrm{b}, \mathrm{A}}$ \\
\hline SEM & & & 0.066 & & \\
\hline \multicolumn{6}{|c|}{$\begin{array}{l}\text { Means in the same row with different superscript letters are significantly different for each type of yogurt. } \\
\text { is Means in the same column with different superscript letters are significantly different for a particular day of } \\
\text { storage for each parameter. }\end{array}$} \\
\hline \multicolumn{6}{|c|}{$\begin{array}{l}{ }^{1} \mathrm{NEY}=\text { control yogurt prepared from skim milk standardized to } 12 \% \text { total solids and non-EPS-producing } \\
\text { strain of } S \text {. thermophilus; EY = yogurt prepared from skim milk standardized to } 12 \% \text { total solids and EPS- } \\
\text { producing strain of } S \text {. thermophilus. }\end{array}$} \\
\hline
\end{tabular}

was significantly higher than that of NEY strain of $S$. thermophilus at $\mathrm{d} 14$ and 21 of storage indicating some protective effect of EPS. Purwandari et al. (2007) however, observed an increase in counts of EY strain of $S$. thermophilus only during the first week of cold storage of yogurt prepared using only $S$. thermophilus. On the other hand, the counts of Lb. delbrueckii ssp. bulgaricus in control (NEY) were lower $(P<0.05)$ than those in experimental (EY) yogurts. They showed sharp decreases $(P<0.05)$ in NEY in the first and second week of storage whereas in EY they decreased $(P<0.05)$ during the first and third week of storage at $4^{\circ} \mathrm{C}$. It was also observed that during fermentation, $L b$. delbrueckii ssp. bulgaricus exhibited an increase of only $1 \log$ cycle in NEY while in EY the increase was by $2 \log$ cycles. This is reflected in the higher numbers $(P<0.05)$ of Lb. delbrueckii ssp. bulgaricus in EY as compared with that in NEY. This implies that Lb. delbrueckii ssp. bulgaricus was able to grow and survive better in the presence of the EPS-producing strain of S. thermophilus. Thus, EPS appears to have a protective effect on Lb. delbrueckii ssp. bulgaricus and to some extent on S. thermophilus. Amatayakul et al. (2006) have also observed the protective effect of EPS on $L b$. delbrueckii ssp. bulgaricus. Salvador and Fiszman (2004) observed a significant decrease in viability of $S$. thermophilus and Lb. delbrueckii ssp. bulgaricus in skim yogurt after $15 \mathrm{~d}$ of storage at $10^{\circ} \mathrm{C}$.

\section{Crude EPS Content}

The EPS content (mg/100 g of yogurt) during storage of EY is presented in Table 2. During fermentation the EY strain of $S$. thermophilus produced $37.43 \mathrm{mg}$ of
EPS per $100 \mathrm{~g}$ of yogurt. The EPS content decreased $(P<0.05)$ to almost one-third the original content at d 7 of storage. There were no significant changes in the content thereafter. The decrease in EPS content could be attributed to the presence of enzymes capable of degrading EPS (Deegest et al., 2002). Purwandari et al. (2007) made a similar observation. However, Amatayakul et al. (2006) have reported an increase in the EPS content during the $28 \mathrm{~d}$ storage while Doleyres et al. (2005) found the content to be stable during the 4 -wk storage period. Variations in the method of estimating the EPS, differences in the types of EPS as well as strain variations could be the possible reasons for the differences observed.

\section{Extent of Proteolysis}

The extent of proteolysis, as measured by the difference in the absorbance $\left(\Delta \mathrm{A}_{340}\right)$ of the yogurt filtrates and the absorbance of the corresponding $0 \mathrm{~h}$ filtrates, is shown in Table 3. Both yogurts, NEY and EY, showed similar degree of proteolysis at d 1 and 7. A significant increase was observed at d 14 (0.265 units) for EY but not for NEY. Thereafter, NEY continued to show significant increases but the extent of proteolysis in EY was similar for the last $2 \mathrm{wk}$ of storage. The proteolytic activity was similar for EY and NEY during the first 2 wk of storage, higher $(P<0.05)$ in EY at d 14 and 21 but toward the end of storage (d 28), NEY showed more $(P<0.05)$ proteolysis. Guzel-Seydim et al. (2005) observed significantly higher proteolysis (measured as tyrosine value) in yogurt prepared using ropy cultures than that prepared using nonropy cultures, both of which showed an increase at d 14 of storage. 
Table 2. Changes in survival of yogurt starters and EPS content during storage of control (NEY) ${ }^{1}$ and experimental (EY) low-fat yogurts at $4^{\circ} \mathrm{C}$ for $28 \mathrm{~d}^{2}$

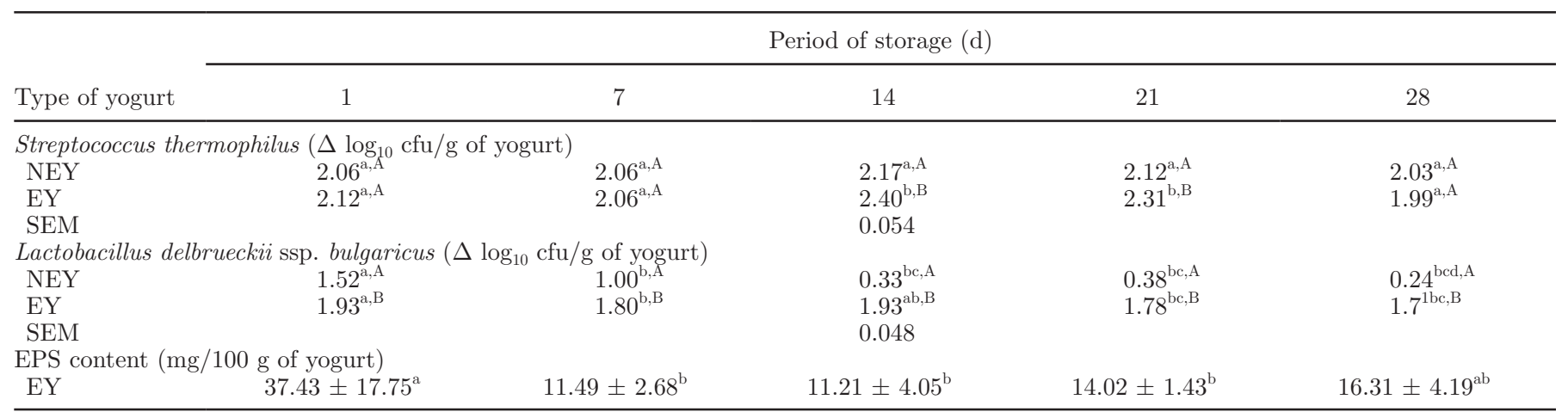

${ }^{\mathrm{a}-\mathrm{c}}$ Means in the same row with different superscript letters are significantly different for each type of yogurt.

${ }^{\mathrm{AB}}$ Means in the same column with different superscript letters are significantly different for a particular day of storage for each parameter.

${ }^{1} \mathrm{NEY}=$ control yogurt prepared from skim milk standardized to $12 \%$ total solids and non-EPS-producing strain of $S$. thermophilus; EY $=$ yogurt prepared from skim milk standardized to $12 \%$ total solids and EPS-producing strain of $S$. thermophilus.

${ }^{2}$ Values are the means of 6 observations.

\section{ACE Inhibition}

The changes in percentage ACE-inhibitory activity and their corresponding $\mathrm{IC}_{50}(\mathrm{mg} / \mathrm{mL})$ values of the yogurt filtrates are depicted in Figure 1. No ACEinhibitory activity was detected in the $0 \mathrm{~h}$ samples of the 2 types of yogurt mixes indicating that ACE inhibition observed in the samples was a consequence of the proteolytic activity of the yogurt starters. An increase $(P<0.05)$ in ACE inhibition was observed at $\mathrm{d} 7$ for both types of yogurt (NEY and EY). Thereafter, while NEY exhibited a decrease $(P<0.05)$ at d 14 followed by an increase $(P<0.05)$ at $\mathrm{d} 28$, EY showed a decrease in ACE-inhibition being significant at d 14 and 28. Although the ACE inhibition of EY was higher at d 14 than that of NEY, the $\mathrm{IC}_{50}$ values were similar because the soluble protein content (data not shown) was significantly higher in EY compared with that in
NEY. The ACE inhibition was similar in NEY and EY throughout the storage period except at d 14 and28 $(P$ $<0.05$ ). These changes could be due to the continued proteolysis to varying extents observed in the yogurts (Table 3) that resulted in hydrolysis of the existing peptides and generation of newer peptides having ACEinhibition potential (Ramchandran and Shah, 2008). It appears that EPS does not offer any particular protection to the ACE-inhibitory potential of the yogurts. This aspect has not been studied so far.

\section{Firmness of Yogurt}

The firmness $(g)$ of the yogurts measured during storage for $28 \mathrm{~d}$ at $4^{\circ} \mathrm{C}$ is presented in Figure 2. The firmness of yogurt prepared from EPS-producing culture $(\mathrm{EY})$ was lower $(P<0.05)$ than that of the control $(\mathrm{NEY})$ at $\mathrm{d} 1$. Both the yogurts showed a significant

Table 3. Changes in extent of proteolysis during storage of control (NEY) ${ }^{1}$ and experimental (EY) low-fat yogurts at $4^{\circ} \mathrm{C}$ for $28 \mathrm{~d}^{2}$

\begin{tabular}{lccccc}
\hline & \multicolumn{5}{c}{ Period of storage (d) } \\
\cline { 2 - 5 } Type of yogurt & 1 & 7 & 14 & 21 & 28 \\
\hline$\Delta \mathrm{A}_{340}$ & & & & \\
NEY & $0.536^{\mathrm{a}, \mathrm{A}}$ & $0.536^{\mathrm{a}, \mathrm{A}}$ & $0.502^{\mathrm{a}, \mathrm{A}}$ & $0.685^{\mathrm{ab}, \mathrm{A}}$ & $0.879^{\mathrm{bc}, \mathrm{A}}$ \\
EY & $0.521^{\mathrm{a}, \mathrm{A}}$ & $0.556^{\mathrm{a}, \mathrm{A}}$ & $0.821^{\mathrm{bc}, \mathrm{B}}$ & $0.794^{\mathrm{bc}, \mathrm{B}}$ & $0.722^{\mathrm{bc}, \mathrm{B}}$ \\
SEM & & & 0.055 & & \\
\hline
\end{tabular}

${ }^{\mathrm{a}-\mathrm{c}}$ Means in the same row with different superscript letters are significantly different for each type of yogurt.

${ }^{\mathrm{AB}}$ Means in the same column with different superscript letters are significantly different for a particular day of storage for each parameter.

${ }^{1} \mathrm{NEY}=$ control yogurt prepared from skim milk standardized to $12 \%$ total solids and non-EPS-producing strain of S. thermophilus; EY = yogurt prepared from skim milk standardized to $12 \%$ total solids and EPS producing strain of $S$. thermophilus.

${ }^{2}$ Values are the means of 6 observations. 


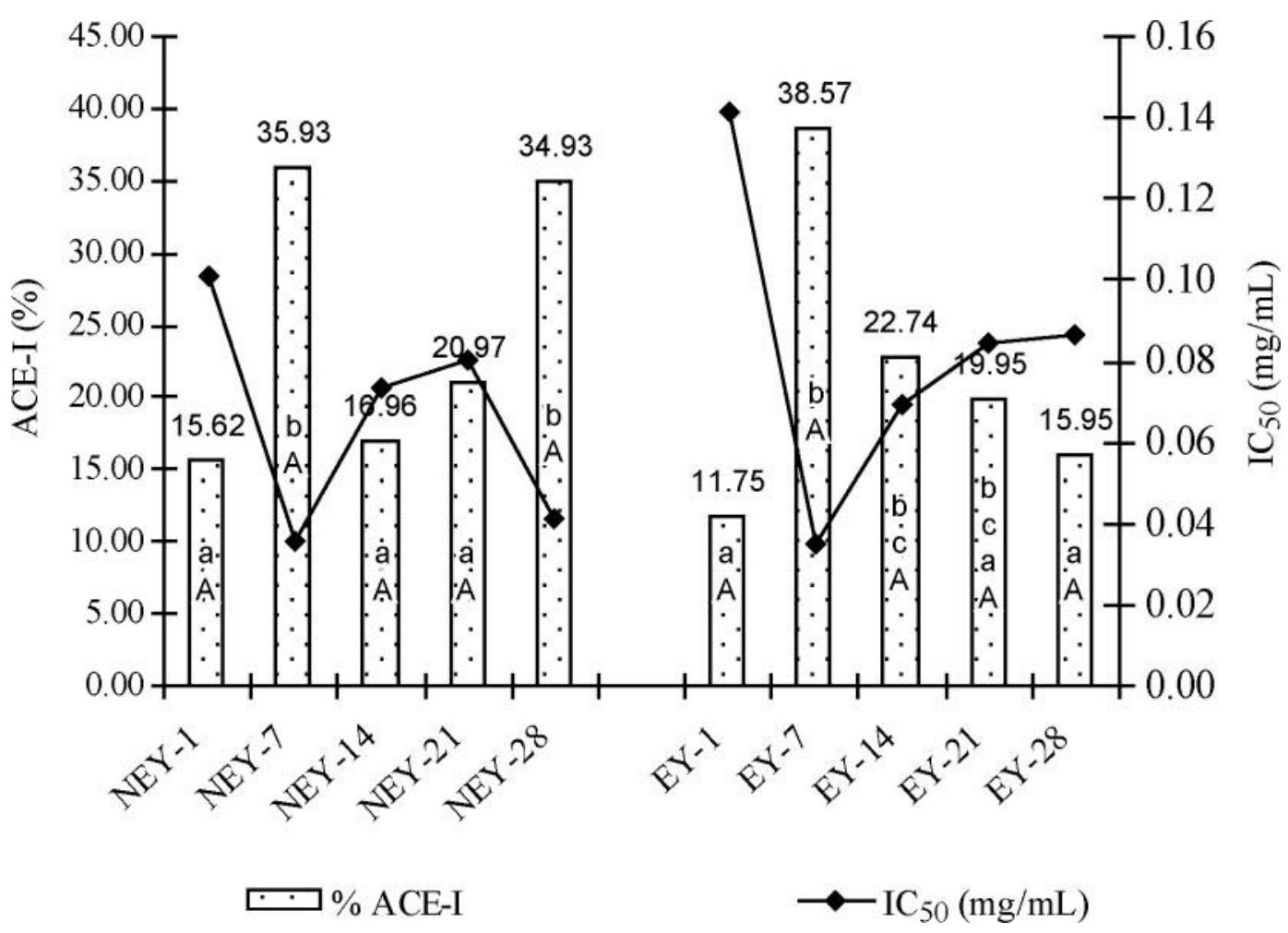

Figure 1. Changes in angiotensin-I converting enzyme (ACE)-inhibition (\%) and $\mathrm{IC}_{50}$ (the protein concentration resulting in $50 \%$ inhibition; $\mathrm{mg} / \mathrm{mL}$ ) values of control (NEY) and experimental (EY) low-fat yogurts during storage at $4^{\circ} \mathrm{C}$ for 28 d. Numbers 1 to 28 following the yogurt types indicates storage period d 1 to $28 .{ }^{\text {a-c }}$ Means with different lowercase letters are different within each type of yogurt; ${ }^{\mathrm{A}, \mathrm{B}}$ means with different uppercase letters are different between each type of yogurt for a particular day of storage.

increase at $\mathrm{d} 7$ after which there was no significant change in their firmness. Throughout the storage period, the firmness of EY was lower $(P<0.05)$ than that of NEY, except at d 14. This clearly indicates that EPS contributes to lowering the firmness of the yogurt gels. Several researchers have made a similar observation using different types of EPS producers (Hess et al., 1997; Hassan et al., 2003b; Amatayakul et al., 2006; Folkenberg et al., 2006). The changes in firmness showed a negative correlation $(\mathrm{R}=-0.89)$ with the changes in EPS content of EY during storage at $4^{\circ} \mathrm{C}$ for $28 \mathrm{~d}$. Folkenberg et al. (2006) also found an inverse correlation between the presence of EPS and gel firmness. It has been reported that in yogurts made using EPS-producing strains, there is incompatibility between EPS and proteins as well as void spaces around EPS-producing bacteria that could result in a weaker network with fewer protein-protein interactions (Ruas-Madiedo et al., 2002; Hassan et al., 2003b). Also, initiation of gelation at relatively higher $\mathrm{pH}$ in these yogurts could result in the formation of densely aggregated networks causing the EPS to aggregate in the continuous phase as aggregation proceeds with the progress in fermentation (Hassan et al., 2003b). It has also been reported that EPS that are weakly charged and, having low molecular weight, reduce the firmness of gels (Girard and Schaffer-Lequart, 2007).

\section{Spontaneous Whey Separation}

Figure 3 shows the changes in spontaneous whey separation observed during the storage of the 2 types of yogurt, NEY and EY. Both types of yogurt showed a significant decrease in whey separation at $d 7$ after which there were no changes, except in the case of NEY, which showed an increase $(P<0.05)$ to a value similar to that at $d 1$. However, the extent of whey separation was significantly reduced in EY, clearly indicating the influence of EPS. Similar effect of EPS has been reported by Amatayakul et al. (2006), Guzel-Seydim et al. (2005), and Hess et al. (1997). The changes in spontaneous whey separation showed a negative correlation with firmness, the correlation being better in EY $(r=-0.65)$ than in NEY $(r=-0.31)$. The better water-holding capacity of EPS and the modification in yogurt structure due to the presence of EPS are plausible explanations for the reduced whey separation. The decrease in whey separation observed during storage 


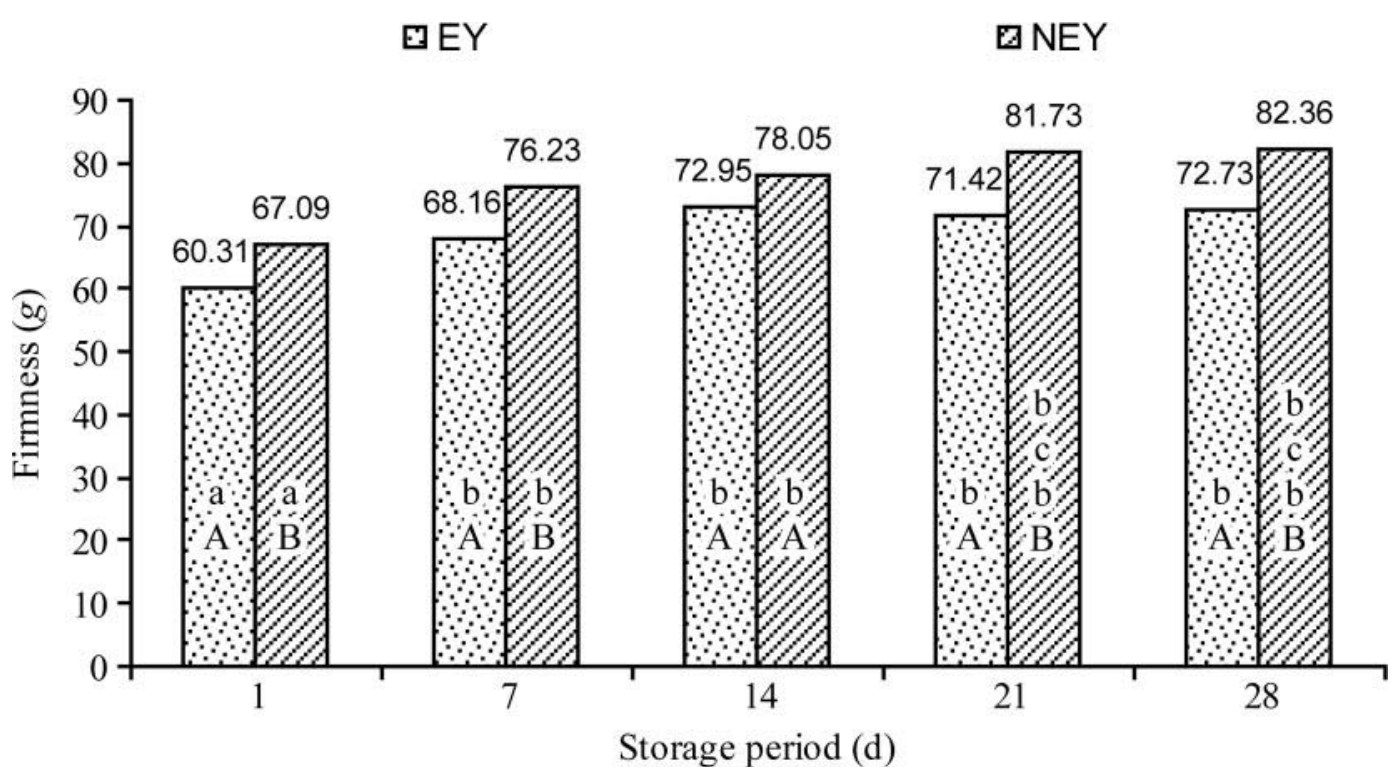

Figure 2. Changes in firmness $(g)$ of control (NEY) and experimental (EY) low-fat yogurts during storage at $4^{\circ} \mathrm{C}$ for $28 \mathrm{~d}$. ${ }^{\text {ac }} \mathrm{Means}$ with different lowercase letters are different within each type of yogurt; ${ }^{\mathrm{A}, \mathrm{B}}$ means with different uppercase letters are different between each type of yogurt for a particular day of storage.

could in part be due to protein rearrangement (Ozer et al., 1998) and partly due to reduction in EPS content resulting in a more thermodynamically stable system with better water-holding capacity (Hassan et al., 2003b). Also, because EY took a longer time to reach $\mathrm{pH} 4.5 \pm 0.1$ than did NEY, it could have resulted in a more compact structure and hence lower syneresis (Hassan et al., 2003b). Castillo et al. (2006) suggested that faster acidification and coagulation reactions enhanced syneresis in cottage cheese gels. Doleyres et al. (2005) also found that yogurts prepared using EPSproducing cultures had better water-holding capacity and thereby lower syneresis, and that the water-holding capacity increased during storage. Although Folkenberg et al. (2006) reported a negative correlation between syneresis and firmness in EPS containing yogurts, they observed that syneresis was more pronounced in EPS containing yogurts.

\section{Rheological Parameters}

To model the flow behavior of the 2 types of low-fat yogurts, NEY and EY, during storage, the upward flow curves (shear stress) were fitted to the Herschel-Bulkley model to obtain yield stress $\sigma_{0}$, consistency index $k$, and flow behavior index $n$ (Table 4 ). The yield stress for NEY was higher $(P<0.05)$ than those of EY throughout the storage period suggesting the influence of EPS. This is in agreement with the higher firmness exhibited by NEY than EY (Figure 2). Doleyres et al. (2005) and Hassan et al. (2003b) made similar observations. The decreased interactions between protein aggregates due to the presence of EPS in the continuous phase surrounding the aggregate is understood to be responsible for this (Hassan et al., 2003b). However, no change in the yield stress was observed for EY throughout the storage period, while for NEY the increase was significant only at $d 21$. The consistency index of EY was, surprisingly, similar to that of NEY until d 14 after which it was lower $(P<0.05)$ than that of NEY. There was no effect of storage time on the consistency index of either NEY or EY. There are conflicting reports for this in literature. Hess et al. (1997) reported a lower consistency index for $\mathrm{EPS}^{+}$yogurts, while Doleyres et al. (2005) and Hassan et al. (2003b) have reported a

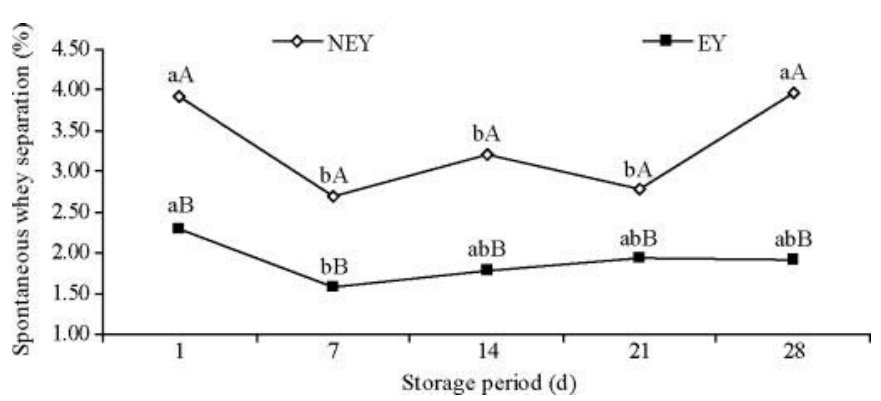

Figure 3. Changes in spontaneous whey separation (\%) during storage of control (NEY) and experimental (EY) low-fat yogurts at $4^{\circ} \mathrm{C}$ for $28 \mathrm{~d}$. ${ }^{\mathrm{a}, \mathrm{b}}$ Means with different lowercase letters are different within each type of yogurt; ${ }^{\mathrm{A}, \mathrm{B}}$ means with different uppercase letters are different between each type of yogurt for a particular day of storage. 
Table 4. Flow behavior (predicted by the Herschel-Bulkley model) and hysteresis loop area of control (NEY) ${ }^{1}$ and experimental (EY) low-fat yogurts during storage at $4^{\circ} \mathrm{C}$ for $28 \mathrm{~d}^{2}$

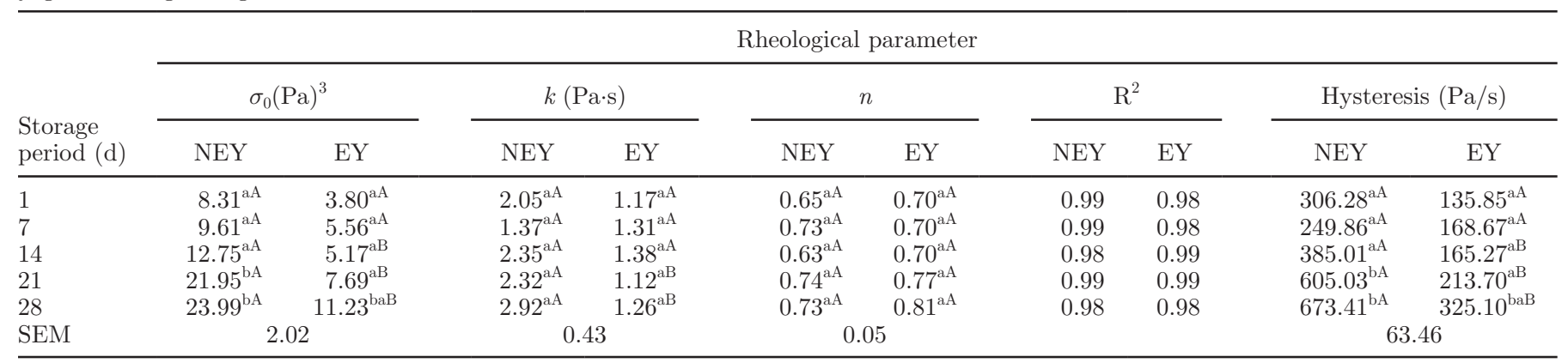

${ }^{\mathrm{ab}}$ Means in the same row with different superscript letters are significantly different for each type of yogurt.

${ }^{\mathrm{AB}}$ Means in the same column with different superscript letters are significantly different for a particular day of storage for each parameter.

${ }^{1} \mathrm{NEY}=$ control yogurt prepared from skim milk standardized to $12 \%$ total solids and non-EPS-producing strain of $S$. thermophilus; EY $=$ yogurt prepared from skim milk standardized to $12 \%$ total solids and EPS-producing strain of S. thermophilus.

${ }^{2}$ Values are the means of 6 observations.

${ }^{3} \sigma_{0}=$ yield stress; $k=$ consistency index; $n$ is a dimensionless number that indicates the closeness to Newtonian flow $(n<1$ indicates pseudoplastic liquid).

higher consistency index and thus a higher viscosity in EPS-containing yogurt than non-EPS-containing ones. However, variations in the viscosifying effect due to variations in type of cultures producing different types of EPS are known (Sebastiani and Zelger, 1998). No variations in the flow behavior index (Table 4) were observed between NEY and EY, nor was there any influence of the time of storage. Doleyres et al. (2005) have also reported that the flow behavior index of yogurts produced with or without EPS-producing starter culture did not differ significantly. However, the low values $(<1)$ of flow behavior index confirm the deviation in flow behavior of yogurts from Newtonian fluids, although there does not appear to be any influence of the presence of EPS.
The thixotropic behavior of NEY and EY as determined by the hysteresis loop area $(\mathrm{Pa} / \mathrm{s})$ between the upward and downward curves (shear rate 0.1 to 100 per s) is presented in Table 4. The higher values for NEY indicate slower structural recovery in these samples than in EY. Girard and Schaffer-Lequart (2007) have reported that weakly charged EPS and low-molecularweight EPS allowed best recovery of the texture of milk gels after shearing. A weak gel made up of loosely bound aggregates may rebuild more easily than brittle ones. The values for NEY were higher than those for EY $(P$ $<0.05$ ) only at $d 14,21$, and 28 . This is in concurrence with the higher consistency coefficients of NEY than EY. The correlation of firmness to hysteresis loop area was also better for NEY $(r=0.75)$ than for EY $(r=$

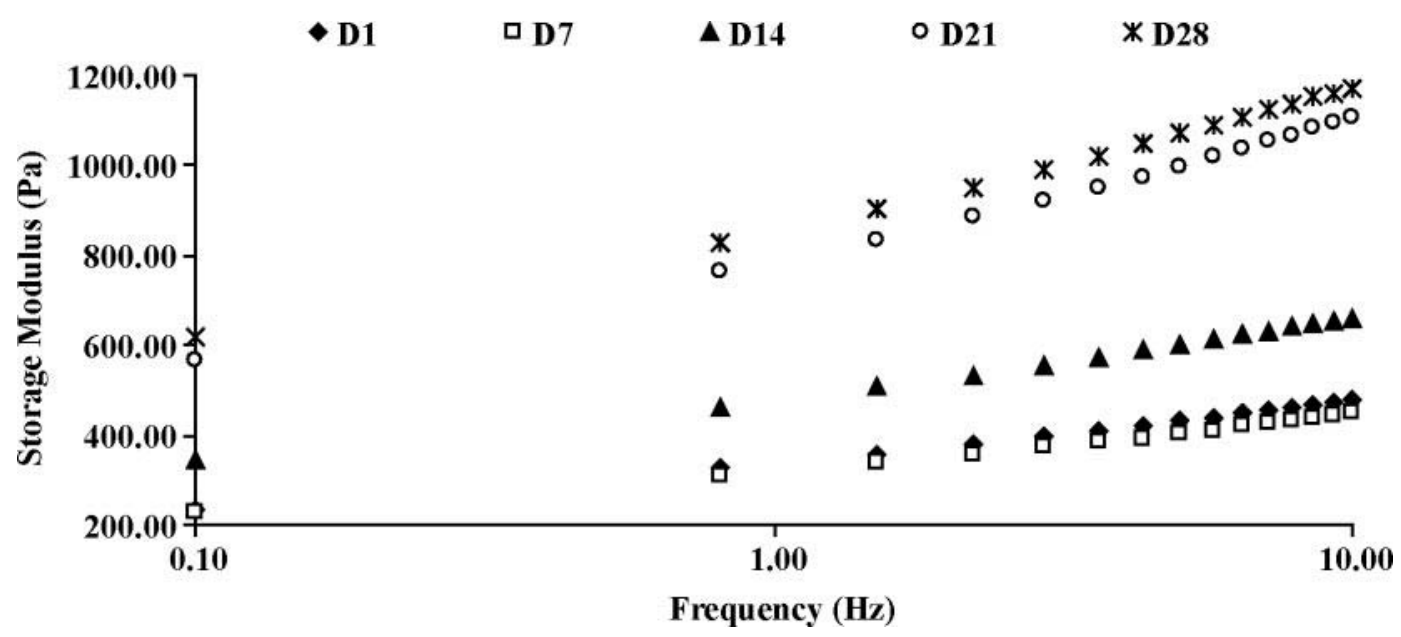

Figure 4. Storage modulus of control low-fat yogurt (NEY) during storage at $4^{\circ} \mathrm{C}$ for $28 \mathrm{~d}$, as a function of oscillatory frequency, carried out at $5^{\circ} \mathrm{C}$. Reported data are means of 6 observations. 


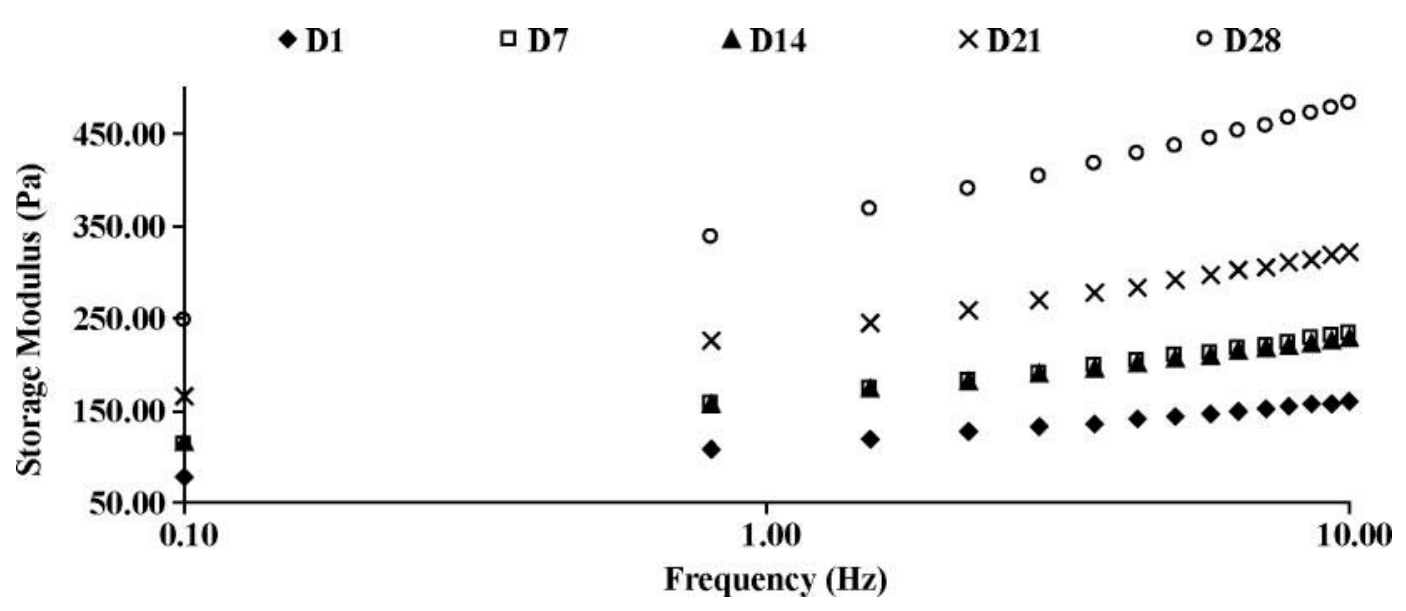

Figure 5. Storage modulus of experimental (EY) low-fat yogurt during storage at $4^{\circ} \mathrm{C}$ for $28 \mathrm{~d}$, as a function of oscillatory frequency, carried out at $5^{\circ} \mathrm{C}$. Reported data are means of 6 observations.

0.60). There was no change in hysteresis area of EY throughout the storage period while an increase $(P<$ 0.05) was observed in NEY at d 21 and 28. However, Amatayakul et al. (2006) found higher loop area values (shear rate 10 to 50 per s) for EPS containing yogurts that varied during storage, whereas Purwandari et al. (2007) have observed greater hysteresis loop area in EPS containing yogurts at the end of storage. Koksoy and Kilic (2004) have found that an increase in consistency coefficient was associated with increased thixotropy.

The results of frequency sweep of NEY and EY, reported as storage modulus $\left(\mathbf{G}^{\prime}\right)$ versus $\log$ frequency, gave a straight line as shown in Figure 4 and 5 respectively. The $\mathrm{G}^{\prime}$ of NEY (482 Pa) was higher than that of EY (161 Pa), as was the loss modulus (G"; 131 and $46 \mathrm{~Pa}$ respectively). Both $\mathrm{G}^{\prime}$ and $\mathrm{G}^{\prime \prime}$ increased with storage to 1172 and $305 \mathrm{~Pa}$ for NEY and 483 and 128 $\mathrm{Pa}$ for EY, respectively. This indicates that NEY had more solid-like (elastic) properties than EY, thereby implying that EPS conferred more viscous properties to the yogurt. This is confirmed by the higher $(P<$ 0.05 ) firmness (Figure 2) and yield stress (Table 4) values of NEY as compared with EY. Extensive particle rearrangement during structure formation resulting in dense clusters of aggregates along with lesser proteinprotein interactions could have caused lower $\mathrm{G}^{\prime}$ values in EY. Purwandari et al. (2007), Doleyres et al. (2005), and Hassan et al. (2003b) have also made similar observations.

\section{CONCLUSIONS}

During storage of the low-fat yogurts, the presence of EPS did not have any influence on changes in $\mathrm{pH}$ and lactic acid content although there was a protective ef- fect on L. delbrueckii ssp. bulgaricus and to some extent on S. thermophilus. The EPS content of EY dropped significantly during the first week of storage and remained stable thereafter. There was a significant increase in the extent of proteolysis in EY at d 14 and in NEY at d 14 and 21 of storage. Exopolysaccharide did not appear to have any influence on the ACE-inhibition activity. However, there was a definite influence of EPS in reducing the firmness, spontaneous whey separation, and yield stress of low-fat yogurt, whereas there was no significant influence on the consistency index and flow behavior index of the yogurts. Yogurts made from EPS-producing starter showed a faster structural recovery after shear and exhibited better viscous properties. Thus, use of EPS producers in low-fat yogurt improved the textural properties of the yogurts without influencing their ACE-inhibition potential.

\section{ACKNOWLEDGMENT}

The authors acknowledge the help provided by Todor Vasiljevic in rheological analysis of yogurt and statistical analysis of the data.

\section{REFERENCES}

Al-Kadamany, E., M. Khattar, T. Haddad, and I. Toufeili. 2003. Estimation of shelf-life of concentrated yogurt by monitoring selected microbiological and physicochemical changes during storage. Lebensm. Wiss. Technol. 36:407-414.

Amatayakul, T., A. L. Halmos, F. Sherkat, and N. P. Shah. 2006. Physical characteristics of yogurts made using exopolysaccharideproducing starter cultures and varying casein to whey protein ratios. Int. Dairy J. 16:40-51.

Bourne, M. 2002. Physics and texture. Pages 59-106 in Food Texture and Viscosity: Concept and Measurement. Academic Press, New York, NY.

Broadbent, J. R., D. J. McMahon, D. L. Welker, C. J. Oberg, and S. Moineau. 2003. Biochemistry, genetics and applications of 
exopolysaccharides production in Streptococcus thermophilus: A review. J. Dairy Sci. 86:407-423.

Castillo, M., J. A. Lucey, T. Wang, and F. A. Payne. 2006. Effect of temperature and inoculum concentration on gel microstructure, permeability and syneresis kinetics. Cottage cheese-type gels. Int. Dairy J. 16:153-163.

Church, F. C., H. E. Swaisgood, D. H. Porter, and G. L. Catignani. 1983. Spectrophotometric assay using o-phthaldialdehyde for determination of proteolysis in milk and isolated milk proteins. J. Dairy Sci. 66:1219-1227.

Clare, D. A., and H. E. Swaisgood. 2000. Bioactive milk peptides: A prospectus. J. Dairy Sci. 83:1187-1195.

Cushman, D. W., and H. S. Cheung. 1971. Spectrophotometric assay and properties of the angiotensin-converting enzyme of rabbit lung. Biochem. Pharmacol. 20:1637-1648.

Dave, R. I., and N. P. Shah. 1996. Evaluation of media for selective enumeration of Streptococcus thermophilus, Lactobacillus delbrueckii ssp. bulgaricus, Lactobacillus acidophilus, and bifidobacteria. J. Dairy Sci. 79:1529-1536.

De Vuyst, L., and B. Degeest. 1999. Heteropolysaccharides from lactic acid bacteria. FEMS Microbiol. Rev. 23:153-177.

De Vuyst, L., M. Zamfir, F. Mozzi, T. Adriany, V. Marshall, B. Degeest, and F. Vaningelgem. 2003. Exopolysaccharide-producing Streptococcus thermophilus strains as functional starter cultures in the production of fermented milks. Int. Dairy J. 13:707-717.

Deegest, B., F. Mozzi, and L. De Vuyst. 2002. Effect of medium composition and temperature and $\mathrm{pH}$ changes on the exopolysaccharide yields and stability during Streptococcus thermophilus LY03 fermentation. Int. J. Food Microbiol. 79:161174 .

Doleyres, Y., L. Schaub, and C. Lacroix. 2005. Comparison of the functionality of exopolysaccharides produced in situ or added as bioingredients on yogurt properties. J. Dairy Sci. 88:4146-4156.

Faergemand, M., M. V. Sorensen, U. Jorgensen, G. Budolfsen, and K. B. Qvist. 1999. Transglutaminase: Effect on instrumental and sensory texture of set style yogurt. Milchwissenschaft 54:563566 .

Folkenberg, D. M., P. Dejmek, A. Skriver, H. S. Guldager, and R. Ipsen. 2006. Sensory and rheological screening of exopolysaccharide producing strains of bacterial yogurt cultures. Int. Dairy J. $16: 111-118$

Girard, M., and C. Schaffer-Lequart. 2007. Gelation of skim milk containing anionic exopolysaccharides and recovery of texture after shearing. Food Hydrocoll. 21:1031-1040.

Gobbetti, M., L. Stepaniak, M. De Angelis, A. Corsetti, and R. Di Cagno. 2002. Latent bioactive peptides in milk proteins: Proteolytic activation and significance in dairy processing. Crit. Rev. Food Sci. Nutr. 42:223-239.

Guzel-Seydim, Z. B., E. Sezgin, and A. C. Seydim. 2005. Influences of exopolysaccharide producing cultures on the quality of plain set type yogurt. Food Contr. 16:205-209.

Hassan, A. N., M. Corredig, and J. F. Frank. 2002. Capsule formation by nonropy starter cultures affects the viscoelastic properties of yogurt during structure formation. J. Dairy Sci. 85:716-720.

Hassan, A. N., J. F. Frank, and M. Elsoda. 2003a. Observation of bacterial exopolysaccharide in dairy products using cryo-scanning electron microscopy. Int. Dairy J. 13:755-762.

Hassan, A. N., R. Ipsen, T. Janzen, and K. B. Qvist. 2003b. Microstructure and rheology of yogurt made with cultures differing only in their ability to produce exopolysaccharides. J. Dairy Sci. 86:1632-1638.

Hayes, M., R. P. Ross, G. F. Fitzgerald, and C. Stanton. 2007. Putting microbes to work: Dairy fermentation, cell factories and bioactive peptides. Part II: Bioactive peptide functions. Biotechnol. J. $2: 435-449$.

Hess, S. J., R. F. Roberts, and G. R. Ziegler. 1997. Rheological properties of nonfat yogurt stabilized using Lactobacillus delbrueckii ssp. bulgaricus producing exopolysaccharide or using commercial stabilizer systems. J. Dairy Sci. 80:252-263.

Hugenholtz, J., and E. J. Smid. 2002. Nutraceutical production with food grade microorganisms. Curr. Opin. Biotechnol. 13:497-507.
Jolly, L., S. J. F. Vincent, P. Duboc, and J.-R. Neeser. 2002. Exploiting polysaccharides from lactic acid bacteria. Antonie Van Leeuwenhoek 82:367-374.

Koksoy, A., and M. Kilic. 2004. Use of hydrocolloids in textural stabilization of a yogurt drink, ayran. Food Hydrocoll. 18:593600.

Lopez-Fandino, R., J. Otte, and J. van Camp. 2006. Physiological, chemical and technological aspects of milk protein-derived peptides with antihypertensive and ACE-inhibitory activity. Int. Dairy J. 16:1277-1293.

Lorenzen, P. C. 2002. Enzymatic crosslinking of dairy proteins. Bull. IDF 374:30-36.

Lowry, O. H., N. J. Rosebrough, A. L. Farr, and R. J. Randall. 1951 Protein measurement with the Folin-Phenol reagent. J. Biol. Chem. 193:265-275.

Lucey, J. A. 2002. Formation and physical properties of milk protein gels. J. Dairy Sci. 85:281-294.

Meisel, H., and W. Bockelmann. 1999. Bioactive peptides encrypted in milk proteins: Proteolytic activation and thropho-functional properties. Antonie Van Leeuwenhoek 76:207-215.

Ozer, B., H. A. Kirmaci, S. Ozetin, A. Hayaloglu, and M. Atamer. 2007. Incorporation of microbial transglutaminase in non-fat yogurt production. Int. Dairy J. 17:199-207.

Ozer, B. H., R. K. Robinson, A. S. Grandison, and A. E. Bell. 1998 Gelation properties of milk concentrated by different techniques. Int. Dairy J. 8:793-799.

Purwandari, U., N. P. Shah, and T. Vasiljevic. 2007. Effects of exopolysaccharide-producing strains of Streptococcus thermophilus on technological and rheological properties of set-type yogurt. Int. Dairy J. 17:1344-1352.

Ramchandran, L., and N. P. Shah. 2008. Effect of addition of Versagel on microbial, chemical and physical properties of low fat yogurt. J. Food Sci. 73:M360-M367.

Ruas-Madiedo, P., J. Hugenholtz, and P. Zoon. 2002. An overview of the functionality of exopolysaccharides produced by lactic acid bacteria. Int. Dairy J. 12:163-171.

Salvador, A., and S. M. Fiszman. 2004. Textural and sensory characteristics of whole and skimmed flavoured set-type yogurt during long storage. J. Dairy Sci. 87:4033-4041.

SAS Institute. 1996. SAS/STAT Software. Changes and Enhancements. SAS Inst. Inc., Cary, NC.

Sebastiani, H., and G. Zelger. 1998. Texture formation by thermophilic lactic acid bacteria. Milchwissenschaft 53:15-20.

Shah, N. 2003. Yogurt: The product and its manufacture. Pages 6252 6259 in Encyclopedia of Food Science and Nutrition. Vol. 10. 2nd ed., B. Caballero, L. C. Trugo and P. M. Finglas, ed. Academic Press, London, UK.

Shah, N. P. 2000. Effect of milk-derived bioactives: An overview. Br. J. Nutr. 84(Suppl. 1):S3-S10.

Sodini, I., F. Remeuf, S. Haddad, and G. Corrieu. 2004. The relative effect of milk base starter, and process on yogurt texture: A review. Crit. Rev. Food Sci. Nutr. 44:113-137.

Tinson, W., M. C. Broome, A. J. Hillier, and G. R. Jago. 1982. Metabolism of Streptococcus thermophilus. 2. Production of $\mathrm{CO}_{2}$ and $\mathrm{NH}_{3}$ from urea. Aust. J. Dairy Technol. 37:14-16.

van Geel-Schutten, G. H., F. Flesch, B. ten Brink, M. R. Smith, and L. Dijkhuizen. 1998. Screening and characterization of Lactobacillus strains producing large amounts of exopolysaccharides. Appl Microbiol. Biotechnol. 50:697-703.

Welman, A. D., and I. S. Maddox. 2003. Exopolysaccharides from lactic acid bacteria: Perspectives and challenges. Trends Biotechnol. 21:269-274.

Xu, Z.-M., D. G. Emmanouelidou, S. N. Raphaelides, and K. D. Antoniou. 2008. Effect of heating and fat content on the structure development of set yogurt. J. Food Eng. 85:590-597.

Zisu, B., and N. P. Shah. 2003. Effects of $\mathrm{pH}$, temperature, supplementation with whey protein concentrate and adjunct cultures on the production of exopolysaccharides by Streptococcus thermophilus 1275. J. Dairy Sci. 86:3405-3415. 